The $B D J$ News section accepts items that include general news, latest research and diary events that interest our readers. Press releases or articles may be edited, and should include a colour photograph if possible. Please direct your correspondence to the News Editor, Arveen Bajaj at the BDJ, The Macmillan Building, 4 Crinan Street, London N1 9XW or by email to bdj@bda.org

\section{Prize for} professionalism winners

The General Dental Council (GDC) has announced this year's winners of the GDC Prize for Professionalism. The Prize for Professionalism gives the GDC an opportunity to recognise the achievements of student dental professionals in the UK. It is an annual prize, sponsored by the GDC Charitable Trust, and makes a financial award to students who have demonstrated professionalism in areas such as patient care, clinical governance, team working, communication skills, reliability, integrity and knowledge. Each UK dental school, school of dental hygiene and school of dental therapy with undergraduates nominates a winner from each of the courses they run.

The dental student winners of the Prize for Professionalism Award 2006 are Christine Gregg from the Queen's University of Belfast School of Clinical Dentistry, Ravi Panesar from the University of Birmingham School of Dentistry, Eleri Jones from the University of Bristol Dental School, Andrea Jane Phillips from Cardiff University School of Dentistry, Eilidh Morgan from Dundee Dental School, Karen Blake from King's College London Dental Institute, Alan Ralph Macleod from University of Glasgow Dental School, Gurminder Singh Jutla from Leeds Dental Institute, Claire Harwood from University of Liverpool School of Dentistry, Shikha Attray from Barts and the London School of Medicine and Dentistry, Rupert Austin from the University of Manchester School of Dentistry, Lee McMahon from the University of Newcastle Upon Tyne School of Dental Sciences and Pankaj Taneja from the University of Sheffield School of Clinical Dentistry.

\title{
Top regional award winners
}

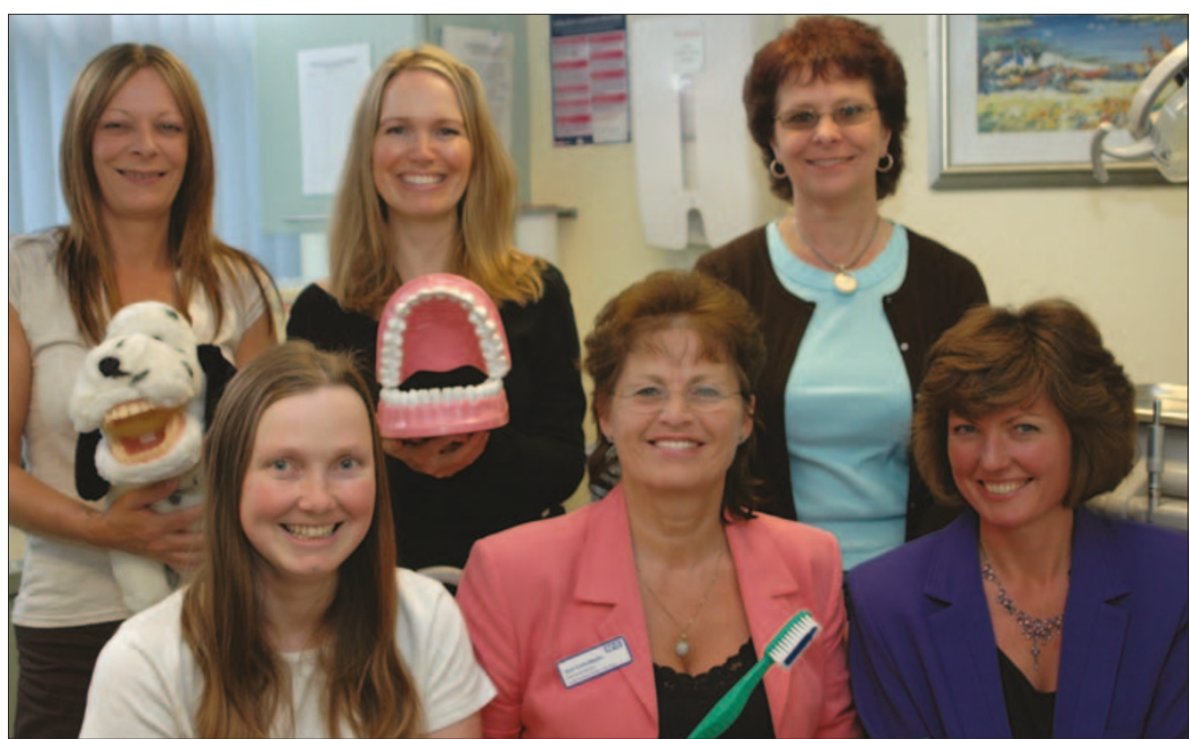

Somerset Smiles, the Somerset Oral Health and Dental Team has been recognised in the Dorset and Somerset NHS Awards 2006. The awards aim to celebrate the innovation and improvement being implemented by teams and individual members of NHS staff in the two counties and to share their successes.

Somerset Smiles received the top award in the Public Health category, taking home the gold medal at a recent regional awards ceremony. It aims to provide a cost effective way of engaging teachers, early years staff and health visitors to help improve the oral and dental health of children. The scheme provides a learning resource pack for staff groups to use with children. The materials in the pack give staff the tools to communicate evidence based public health information to children in a way that they can understand.

The project focused on schools and Sure Start centres in areas where it has been identified that children are at the highest risk of developing dental decay. The long term vision is to roll the scheme out to all pre-school and primary school children across Somerset. Sarah Pittwood, Oral Health Coordinator said, "We are extremely pleased and proud to receive this award. This award brings important recognition to the team and helps to raise the profile of oral health education." Pictured above, Somerset Smiles Oral Health and Dental Team.

\section{Complaints resolved promptly}

The first 100 days of the new Dental Complaints Service, which helps resolve complaints about private dental care, have seen it resolve most complaints in less than two and a half days, it reports.

Of the 520 complaints the service received since it launched earlier this year, on May 24, it closed 484 complaints, with a success rate of 99.7 per cent. At the end of 100 days, just 15 of the most recent complaints were still outstanding.

Resolving complaints may involve recommending an apology to the patient, a refund of fees and/or a contribution by a dental practice towards the costs of remedial treatment.

It may also involve helping the patient to understand that their complaint is unjustified.

The Service received more than 2,000 enquiries to its complaints hotline, half of them about NHS dental services, which were redirected to the appropriate local NHS contact. 


\section{Healthy smiles in the Blue Mountains of Jamaica}

A charity that promotes sustainable community development for rural Jamaican communities by providing assistance with basic healthcare, educational resources, and training opportunities is looking for volunteers.

The Blue Mountain Project's Hagley Gap Health Clinic offers free basic services such as basic health checks, wound cleanings, blood pressure checks, blood sugar testing, mental health counselling and health education.

The Project's first initiative in Hagley Gap and surrounding communities was to arm every school child with a toothbrush and the knowledge of how to use it properly. This was done with a felt tooth costume, felt food particles and giant toothbrush in the local schools. For many children, the Blue Mountain Project provided their first toothbrush. Sarah Beamer, Operations Manager at the Project set up the beginnings of the Blue Mountain Project Health Clinic in 2004, which consisted of two lawn chairs in a court yard and a back pack full of medical supplies. According to the organisation, dental care is so scarce in the Blue Mountains that most do not make it into adulthood without the loss of teeth.

During the annual Health Fair in June, a booth was set up with toothbrushes, toothpaste, a mirror and the pink plaque tablets. Everyone was given a new toothbrush, some toothpaste and asked to brush their teeth. When they returned they were able

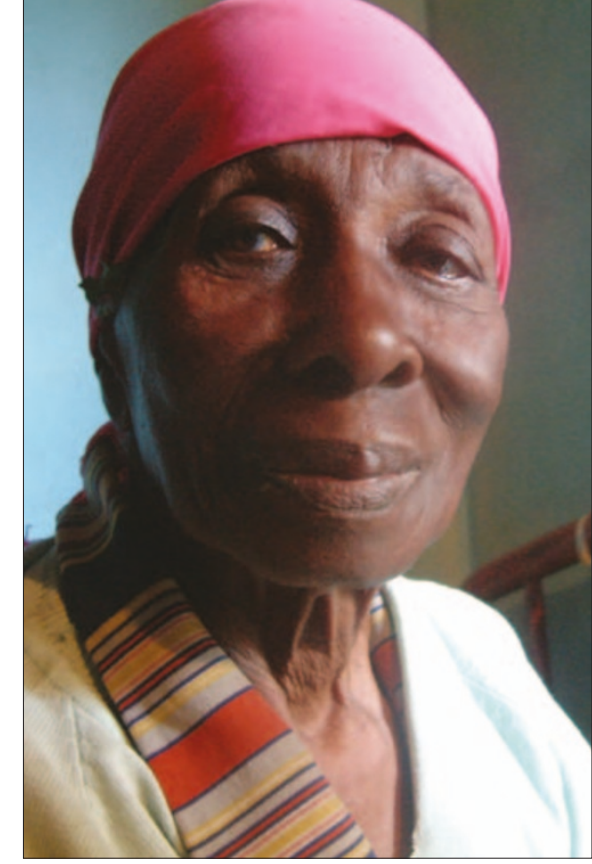

to check the job they did with the pink tablet and the mirror, reinforcing oral health routine lessons.

Volunteer dental teams should expect to do a large amount of oral exams, oral hygiene instruction, prophylaxis, fluoride treatments, dental sealants, scaling and root planing, extractions, and simple restorative procedures, such as amalgam and composite restorations. For more information visit www.bluemountainproject.org.

\section{New lead in cleft lip and palate research}

Researchers claim to have identified another gene that can cause cleft lip and palate, one of the world's most common birth defects. The researchers, supported by the National Institutes of Health, USA, report in the current issue of the journal Science that a much-studied gene called SUM01, when under expressed, can cause cleft lip and palate.

With several genes already implicated in causing cleft lip and palate, the authors note their addition to the list comes with a unique biological twist.

The SUM01 gene encodes a small protein that is attached to the protein products of at least three previously discovered 'clefting' genes during facial development, in essence linking them into or near a shared regulatory pathway and now hotspot for clefting.

\section{Death notice}

Ian Beedie LDS, aged 87, late of Sunderland/Appleby in Westmorland, recently passed away at Penrith Hospital on 12 September 2006.

\section{Warning over 'Meth mouth'}

Methamphetamine is a powerfully addictive drug that can seriously damage oral health, destroying a person's smile and natural ability to chew, according to the American Dental Association (ADA).

More than 12 million Americans have tried methamphetamine (also known as meth, crank, crystal and speed), which can be swallowed, injected, snorted or smoked, according to the 2004 National Survey on Drug Use and Health. The majority of users range between 18 and 34 years of age.

'Meth' users can go from having healthy teeth to extremely sensitive teeth and eventual tooth loss in about a year, warns the ADA. This condition is often called 'meth mouth' Meth mouth robs people, especially young people of their teeth and frequently leads to full-mouth extractions and a lifetime of wearing dentures, says Robert M. Brandjord, ADA President. "Meth mouth is characterised by rampant tooth decay and teeth described by meth users as blackened, stained, rotting, crumbling or falling apart," $\mathrm{Dr}$ Brandjord explains. "The extensive tooth decay of meth mouth is attributed to the drug's dry-mouth effect and its propensity to cause cravings for high-calorie carbonated beverages, tooth grinding and clenching, and extended periods of poor oral hygiene."

In an effort to highlight this condition, the ADA has posted educational materials on its website www.ada.org for both dentists and patients and recently distributed a video news release with The Partnership for a Drug-Free America at www.drugfree.org/meth.

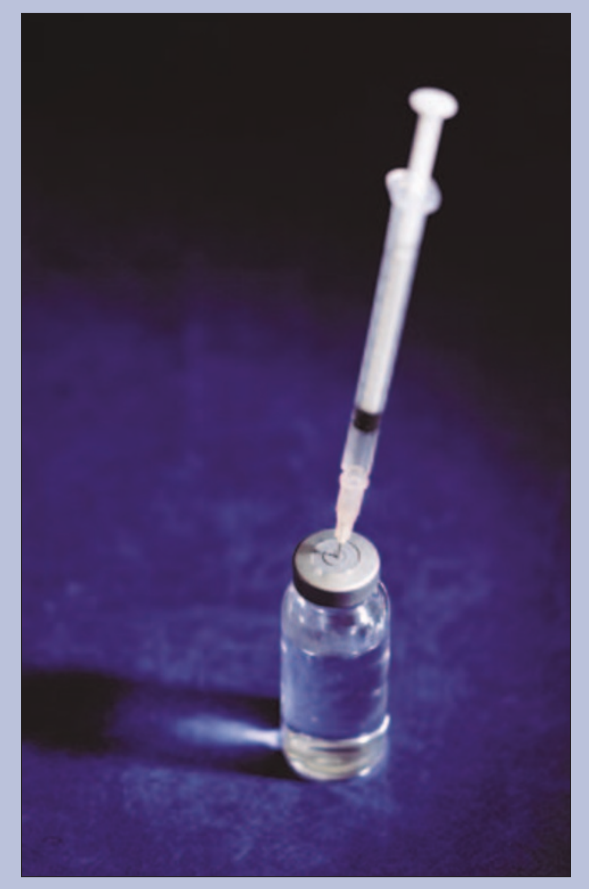




\section{Special find}

An extraordinary set of 18th Century dentures has gone on public display for the first time at the Museum of London. The 200-year old set of false teeth belonged to Arthur Richard Dillon (1721-1806), Archbishop of Narbonne in France. Archaeologists discovered them, still snugly fitting in his mouth, when they opened his coffin in London's St Pancras graveyard during excavations in advance of construction work at the Channel Tunnel Rail Link's new London terminus.

Made of porcelain with gold springs, and individually crafted for a perfect fit, dentures such as these were invented in France in the 1770s. Dillon possibly bought them from the celebrated Parisian dentist, Nicholas De Chemant, before fleeing to England at the time of the Revolution.

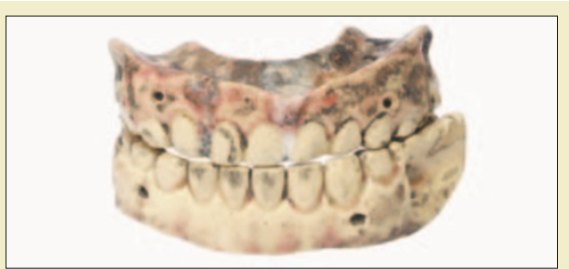

This unique archaeological discovery is a poignant memento of a leading and colourful figure in the French émigré community. Museum of London specialist Natasha Powers, working with Gifford Archaeology on the project, wrote a paper on the teeth for the $B D J(B D J 2006 ; 201$, 459-463). She said, "These unique artifacts reflect a pivotal time in dental history, with the adoption of new materials and methods of manufacture. They also represent a period of significant social and economic change for the upper echelons of French society."

\section{Periodontal disease and coronary heart disease}

Researchers found an increased risk of coronary heart disease for people below the age of 60 who have more than four millimeters of alveolar bone loss from periodontal disease, according to a new study in the Journal of Periodontology.

It was found that participants with coronary heart disease had an increase in periodontal disease indicators, including alveolar bone loss, clinical attachment loss and bleeding compared to the group without coronary heart disease.

"This study is distinctive because to our knowledge, it is the first to include both the alveolar bone loss and full mouth recording of clinical attachment loss as measurements of periodontal disease," explains Dr Karen Geismar, Department of Periodontology, School of Dentistry, Faculty of Health Science, University of Copenhagen, Denmark. "Alveolar bone loss was recently found to be the periodontal variable that had the strongest association to coronary heart disease."

The study included 110 patients with coronary heart disease and 140 people without coronary heart disease. The mean age was 65 years and 70 percent of the participants were male; all 250 participants received a medical and dental examination. Researchers found a significantly higher odds ratio of 6.6 for individuals below age 60 having being a patient with coronary heart disease when having a mean alveolar bone loss of

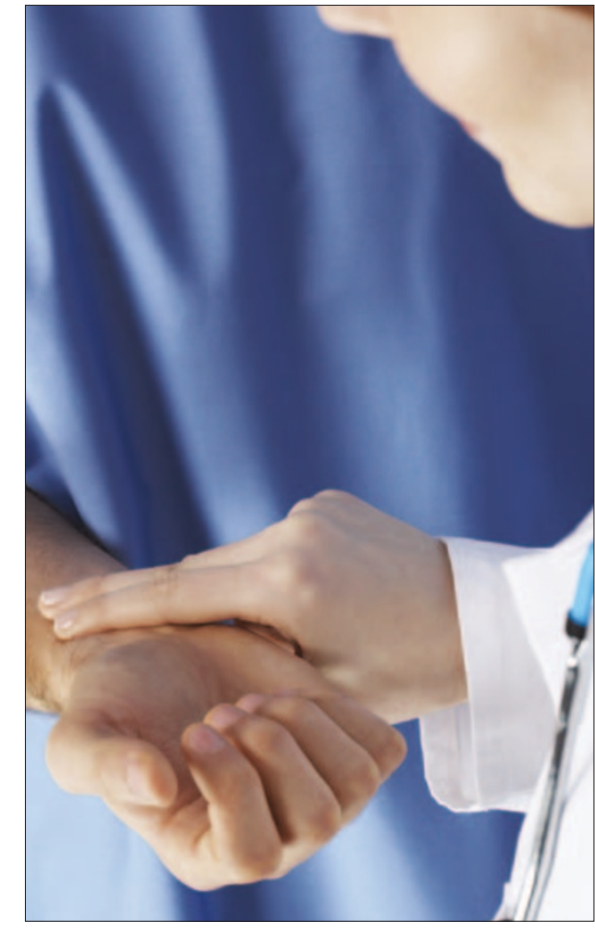

more than four millimeters.

The association between periodontal disease and coronary heart disease has been that chronic infections and the inflammatory response from diseases such as periodontal disease may be involved in the initiation and progression of atherosclerosis.

"A number of pathways are suspected to be involved," said Dr Geismar. "One way is that periodontal bacteria directly invade the arterial wall and another way is that bacterial products from the periodontal pocket exert a systemic effect on atherosclerosis development based on the immune system." 


\section{DIARY}

November

BDA events -

A clinical guide to periodontology Venue: Marriott Hotel Regent's Park, London Date: 3 November 2006

www.bda-events.org

British Academy of Cosmetic Dentistry's (BACD) 2nd Annual Conference Venue: Britannia International Hotel, London

Date: 16-17-18 November 2006

Email:info@bacd.com

www.bacd.com

\section{The 2006 ADF Conference and Trade Exhibition}

Date: 21-25 November 2006

Venue: Palais des Congrès de Paris, France Email:adf@adf.asso.fr

www.adfcongres.com

\author{
Moving to Private Practice - \\ practical considerations \\ Date: November 242006 \\ Venue: Macrobert Arts Centre, Stirling, \\ Scotland
}

www.bda-events.org

Health Protection Agency: Laser and IPL Sources Safety Training for Medical and Cosmetic Applications

Venue: HPA Radiation Protection

Division, Leeds

Date: 28 November 2006

Telephone: 01132679041

www.hpa.org.uk

\section{December}

LDC officials' day 2006

Date: 1 December 2006

Venue: Tower Hotel, London

www.bda-events.org

\section{New dental contract makes impact on numbers}

Just under 19,500 dentists have signed up to provide NHS treatments, under the new dental contract that came into effect in England on 1 April 2006, according to figures published by the Department of Health's Information Centre for health and social care.

The new contract replaced the previous General Dental Services (GDS) and Personal Dental Services (PDS) arrangement. During the first quarter of the new contract nearly 4.8 million claims for courses of NHS dental treatments were processed (April to June 2006).

Reacting to the publication of the statistics, the British Dental Association has noted that they confirm the decreased number of dentists working in the NHS since the implementation of reforms on 1 April. The figure dropped from 21,111 in the last quarter of the old arrangements, to 19,462 in the first quarter of the new contract for dentists. Also published were figures showing that, as of 31 August 2006, 1,373 of the new contracts originally signed by dentists 'in dispute' are yet to be resolved. That compares to 1,653 a month earlier. According to the latest figures, 2,773 contracts were originally signed in dispute.

Commenting on the reports, Lester Ellman, Chair of the BDA's General Dental Practice Committee, said, "At a time when the government is trying to increase access to NHS dentistry, the loss of any dentist to the service has an impact. These figures reflect the uncertainty felt by dentists and patients alike. The significant number of contracts that were signed in dispute and that are yet to be resolved, means that uncertainty is set to continue. At the current rate, it will be 2007 before all of these disputes are resolved."

\section{Collaboration to raise cash for oral health charity}

Dental charity Dentaid has partnered with dental payment plan provider Denplan in an initiative to raise $£ 1$ million over the next five years. The money raised will be used to support Dentaid's development of innovative and groundbreaking oral health initiatives. One such project is a unique schools programme providing children in Uganda with free oral screening and treatment, oral health education using culturally appropriate materials and toothbrushes and toothpaste as part of a supervised tooth brushing programme.

The project is part of a wider sustainable development programme, which Dentaid is hoping to roll out throughout many disadvantaged communities in the developing world

Denplan aims to raise the money by working with its 6,000 member practices and employees to promote Dentaid's cause and initiatives and to encourage everyone to get behind the charity and become involved in fundraising activities and events.

"Many of our member dentists already support Dentaid and have raised considerable amounts of money through events such as sponsored cycle rides, treks and fancy dress days and I'm sure they will want to get involved in the exciting events programme we have planned over

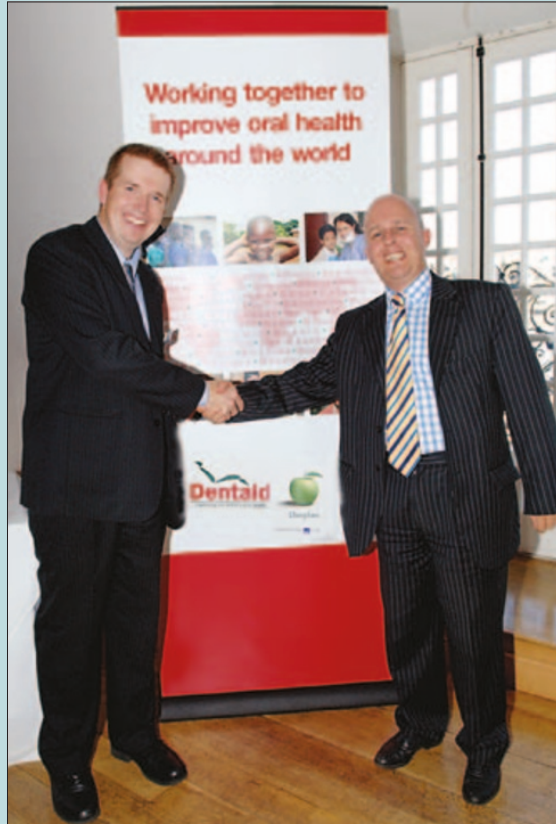

the next few years," commented Stephen Gates, Managing Director, Denplan.

A full programme of events and activities is currently being organised for 2007. If you would like to get involved or to find out further information please contact Jenni, Corporate Relations Officer at Dentaid on 01794324249 or email jenni@dentaid.org. 


\section{New online library catalogue now available}

The BDA's Information Centre launched its new Amlib NetOpac online catalogue at London ExCeL's Dental Showcase exhibition recently. The new system will allow anyone with a computer and internet access to search the BDA Library's catalogue, which holds thousands of records.

The catalogue records include books, journals and references to British Dental Journal and BDA News articles, pamphlets, packages of articles, audiovisual material and rare books. The intention is to gradually build up the database upon which the catalogue is based to include value-added information in addition to bibliographic data.

Roger Farbey, Head of Library Services commented, "This new system represents a quantum leap in our ability to offer our services to members all over the country even when we are closed. It means that any member with a computer and inter- net access can check what books we have available to borrow in the library, but in addition members can see what items they have on loan and also renew or reserve items themselves.

"The new NetOpac system will also allow other libraries and researchers to check the BDA library's catalogue which is in keeping with common practice amongst most major libraries."

Amlib's library management system was originally developed in Australia and has been in use for over ten years. It is one of Australia's leading library systems and is now used worldwide. The BDA Information Centre's NetOpac is available through the library pages of the BDA website at www.bda.org. For further details please contact the Information Centre at InfoCentre@bda.org or telephone 02075634545 (9am-6pm Monday to Friday).

\section{Dentists' addresses to go online}

The General Dental Council (GDC) is to publish the full addresses of GDC-registered dental professionals on its website from 2007. GDC registrants can use their work address, a PO Box, or select their home address. Until now, registrants' full addresses have also been made available in a printed form via the Dentists Register, Rolls of Dental Auxiliaries, and Lists of Dental Specialists, published once a year. However, the GDC has decided to discontinue the printed versions of the registers after this year to give patients, employers and others better access to up to date information about registered dental professionals. The printed versions of the registers could not be amended to reflect any changes that took place during the year, whereas the online registers are updated daily.

\section{Views sought on guidance}

The General Dental Council (GDC) has developed and consulted upon a number of draft policy and guidance documents to support and underpin the operation of its new Fitness to Practice committees, whose powers came fully into effect in July 2006.

The GDC is now seeking views on three further draft policy and guidance documents to complete this present series of guidance. They cover the Professional Performance Committee, the Health Committee and preliminary meetings prior to fitness to practice hearings.

A preliminary meeting should enable directions about procedure and evidence to be given in advance of the formal hearing, where this would assist a fitness to practice committee in performing their functions fairly, justly and efficiently.

To access the consultation documents, please vist the GDC homepage and click on the 'GDC consultation' tab. For a hard copy of the consultation documents, please contact Laura Brown (email: ftpconsultations@gdc-uk.org, phone 020 7009 2719). The closing date for responses to the consultation is Friday 27 October 2006.

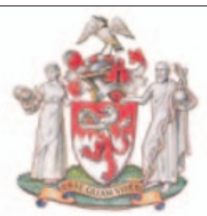

General Dental Council 